\title{
Thermal Stability of Chlorophyll Pigments in Virgin Olive Oil
}

\author{
Holem H. RASUL ${ }^{1}$, Ahmet L. INANC ${ }^{2}$ \\ ${ }^{1}$ KSU, Graduate School of Natural \& Applied Sciences, Dept. of Bioengineering Sciences, Kahramanmaras, Turkey \\ ${ }^{2}$ KSU, Faculty of Agriculture, Dept. of Food Engineering, Kahramanmaras, Turkey
}

Received (Geliş): 15.07.2014

Accepted (Kabul): 26.09.2014

\begin{abstract}
The aim of the present study was to determine the changes in the chlorophyll content and the $\mathrm{K}_{232}$ and $\mathrm{K}_{270}$ specific extinction coefficient values in virgin olive oil (VOO) subjected to high temperatures for $24 \mathrm{~h}$. VOO, was obtained from Kahramanmaraş city, Turkey, and subjected to $150,160,170,180.190$ and $200^{\circ} \mathrm{C}$ for 2, 4, 6, 8, 10,12 and $24 \mathrm{~h}$, and the chlorophyll content and the $\mathrm{K}_{232}$ and $\mathrm{K}_{270}$ specific extinction coefficient values were determined. The chlorophyll content of VOO decreased significantly as the treatment temperature and the extent of heat treatment increased $(P<0.05)$ Especially, the temperature above $180^{\circ} \mathrm{C}$, the chlorophyll content decreased below $3 \%$ after $24 \mathrm{~h}$. The $\mathrm{K}_{232}$ and $\mathrm{K}_{270}$ specific extinction coefficient values of VOO increased significantly with increasing the treatment temperature and time $(P<0.05)$. The values of $\mathrm{K}_{232}$ and $\mathrm{K}_{270}$ specific extinction coefficients reached to 9.12 and $5.28(1 \%, 1 \mathrm{~cm})$, respectively, at $200^{\circ} \mathrm{C}$ after $24 \mathrm{~h}$. However, the rates of the increase in these values did not change with respect to different temperature and time. A significant inverse relationship was found between the chlorophyll content and the $\mathrm{K}_{232}$ and $\mathrm{K}_{270}$ specific extinction coefficient values $(P<0.05)$. This study showed that chlorophyll, as one of the major quality criteria for olive oils, is heat-liable, and decomposes at high temperatures and long treatment times. In addition, increases in the conjugated diene and triene contents of VOO indicate the accelerated oxidation reactions at high temperatures; therefore VOO is no longer classified as "virgin olive oil" according to the official standards.
\end{abstract}

Keywords: Virgin olive oil, chlorophyll, conjugated diene and triene, thermal stability

\section{Natürel Zeytin Yağındaki Klorofil Renk Maddelerinin Isısal Kararlılığı}

Özet: Bu çalışmanın amacı, yüksek sıcaklıklara maruz bırakılan natürel zeytinyağında klorofil ve konjuge bağların miktarlarındaki değişimi 24 saat süresince belirlemektir. Kahramanmaraş, Türkiye'den temin edilen natürel zeytinyağ $1,150,160,170,180.190$ ve $200^{\circ} \mathrm{C}$ sicaklıklarda $2,4,6,8,10,12$ ve 24 saat bekletilmiş ve natürel zeytinyağının klorofil miktarı ve 232 ve 270 nm'deki absorbans değerleri ölçülmüştür. Natürel zeytinyağının klorofil miktarı sıcaklık ve süre arttıkça istatistiksel olarak önemli oranda düşüş göstermiştir $(P<0,05)$. Özelikle, $180^{\circ} \mathrm{C}$ üzeri sıcaklıklarda 24 saat işlem gören sızma zeytinyağında klorofil miktarı \%3'ün altına düşmüştür. Natürel zeytinyağının $\mathrm{K}_{232}$ ve $\mathrm{K}_{270}$ absorbans değerleri, sıcaklık ve sürenin artışına paralel istatistiksel olarak önemli oranda artmıştır $(P<0,05) .200^{\circ} \mathrm{C}$ sicaklıkta ve 24 saat sonunda natürel zeytinyağının $\mathrm{K}_{232}$ absorbans değeri $9,12(1 \%, 1 \mathrm{~cm})$ ve $\mathrm{K}_{270}$ absorbans değeri 5,28 (1\%, $\left.1 \mathrm{~cm}\right)$ 'ye ulaşmıştır. Ancak, farklı sıcaklık ve süreler sonunda $\mathrm{K}_{232}$ ve $\mathrm{K}_{270}$ absorbans değerlerindeki artış hızı hemen hemen sabit kalmıştır. Lineer regresyon analizinde, klorofil miktarındaki düşüş ile $\mathrm{K}_{232}$ ve $\mathrm{K}_{270}$ absorbans değerlerindeki artış arasında istatistiksel olarak önemli negatif bir ilişki bulunmuştur $(P<0,05)$. Sonuç olarak, natürel zeytinyağının kalite göstergelerinden olan klorofilin ısıya karşı duyarlı olduğu ve uzun süre sıcaklık uygulamalarından olumsuz etkilendiği görülmüştür. Ayrıca, yüksek sıcaklıkla meydana gelen oksidasyon reaksiyonları zeytinyağında konjuge bağların artışına neden olmuştur. Bulunan $\mathrm{K}_{232}$ ve $\mathrm{K}_{270}$ absorbans değerleri, resmi standartlarda verilen değerleri aştı̆̆ için natürel zeytinyağı vasfinı yitirmiştir.

Anahtar kelimeler: Natürel zeytinyağı, klorofil, konjuge bağ, 1sı kararlığı

\section{INTRODUCTION}

Virgin olive oil (VOO) is obtained from the olive fruits using solely mechanical or other physical means, which do not alter the oil quality in any way. It has not undergone any sort of chemical treatments (use of solvents or re-esterification methods etc.), other than washing, decanting, centrifuging, and filtering. This creates authenticity for the VOO, and distinguishes it from other edible vegetable oils in terms of aroma, taste, color, nutritional properties and oxidative stability (Morello et al., 2004; Angerosa et al., 2006; Tsimidou, 2006).

In the last few years, interest in VOO, traditionally consumed in the Mediterranean area, has been extended to other countries (Northern Europe, USA, Japan, etc.) due its highly appreciated organoleptic and nutritional characteristics by the consumers. The healthy benefits of VOO arise from its chemical composition and have traditionally been attributed to the high content of monounsaturated acids (oleic acid) and minor components such as phenolics, tocopherols and carotenoids (Angerosa, 2002; Boskou et al., 2006; Perez-Jimenez et al., 2007). The positive influence of VOO on health include an improvement in blood lipid profile by lowering the total and LDL (Low Density Lipoproteins)-cholesterol levels while significantly raising the level of HDL (High density Lipoproteins)cholesterol in the blood stream, reducing degenerative 
and coronary heart diseases, diabetes, certain cancer risks such as breast, prostate and colon cancers, and certain malignant tumors (endometrium, digestive tract, skin tumors) (Anon, 2004; Ozyilkan et al., 2005; Visioli et al., 2006; Perez-Jimenez et al., 2007).

The color of VOO is an important characteristic of quality, and plays a key role as a factor of acceptability among consumers. In fact, many consumers particularly appreciate a deep green color in oil, like in VVO. The green-yellowish color of $\mathrm{VOO}$ is due to various pigments, i.e. chlorophylls, pheophytins and carotenoids, distinguishing it from other vegetable oils (Cichelli and Pertesana, 2004; Del Giovine and Fabietti, 2005; Boskou et al., 2006). However, the oxidative stability of VOO is greatly affected by the presence of these compounds and their derivatives.

VOO provides a rich source of natural antioxidants. These include carotenoids, tocopherols and phenolic compounds which have been reported to play a key role in preventing lipid oxidation by different mechanisms (Aparicio et al., 1999; Cichelli and Pertesana, 2004; Morello et al., 2004). On the other hand, chlorophylls and the pheophytins in presence of the light act as catalysts in the formation of singlet state oxygen, which reacts with unsaturated fatty acids and produces fatty acid hydroperoxides. Decomposition of these hydroperoxides initiates a free-radical type of autoxidation. This photooxidation results in a change in color and, because of the formation of hydroperoxide decomposition products, develops undesirable odor and flavor constituents (Chen and Liu, 1998; Endo et al., 1984; Rahmani and Csallany, 1998). Thus, prevention of oxidation reactions in VOO is of great importance to ensure palatability, economy, and nutritional value.

The objective of the present study was to evaluate the changes in the chlorophyll and conjugated diene and triene contents in the VOO with temperature and the extent of heat treatment. The results of the study will help us understand the fate of chlorophyll during the oxidation reactions.

\section{MATERIAL and METHODS}

\section{Material}

VOO from the olives in 2012-2013 harvest seasons was obtained from a local olive oil plant (Demirkol Ltd., Kahramanmaraş). The characteristic of the olive oil are as follows: free acidity, $0.49 \%$ (as oleic acid); peroxide value, 5.22 meqO$_{2} \mathrm{~kg}^{-1} ; \mathrm{K}_{232}$ and $\mathrm{K}_{270}$ extinction coefficients, 1.89 and 0.15 , respectively; total phenolic content, $65.2 \mathrm{mg}$ tannic acid $\mathrm{kg}^{-1}$, and chlorophyll content, $200 \mathrm{mgL}^{-1}$.

\section{Sample Preparation}

The oil samples $(25 \mathrm{ml}$ each) were transferred into $50 \mathrm{ml}$ serum bottles. The serum bottles were sealed airtight with Teflon-coated rubber seals and aluminum caps and heated to $150,160,170,180,190$ and $200^{\circ} \mathrm{C}$ under dark condition in a forced air oven. All samples were prepared in duplicate. Chlorophyll and conjugated diene and triene contents were measured periodically every 2 -h intervals until the time at which chlorophyll content decreased to $1 \mathrm{mgL}^{-1}$.

\section{Determination of Chlorophyll content in VOO}

Chlorophyll content in oil samples was determined by reading the absorbance at 630,670 and $710 \mathrm{~nm}$ in a $10 \mathrm{~mm}$ spectrophotometer cell against air as described by Pokornyet al. (1995) and expressed as milligrams of pheophytin "a" per kilogram of oil. The method is suitable for the determination of quantities of chlorophylls higher than $1 \mathrm{mgkg}^{-1}$. The following equation was used for the determination of total chlorophyll content in VOO: $\left.A_{710}\right) L^{-1}$

$$
C=345.3 \times\left(A_{670}-0.5 \times A_{630}-0.5 \times\right.
$$

where; $\mathrm{C}$ is the content of chlorophylls ( $\mathrm{mg}$ pheophytin "a"kg-1 oil), A is the absorbance at the respective wavelength $(\mathrm{nm})$, and $\mathrm{L}$ is the thickness of the spectrophotometer cell $(\mathrm{mm})$.

\section{Determination of Conjugated Diene and Triene Contents}

Content of conjugated dienes as absorbance at 232 $\mathrm{nm}\left(\mathrm{A}_{232}\right)$ and content of conjugated trienes as absorbance at $270 \mathrm{~nm}\left(\mathrm{~A}_{270}\right)$, were determined by dissolving weighed-out samples in isooctane $(0.1 \%)$ and reading the sample absorbance at $232 \mathrm{~nm}\left(\mathrm{~A}_{232}\right)$ and 270 $\mathrm{nm}\left(\mathrm{A}_{270}\right)$, using a UV/VIS double-beam scanning spectrophotometer (Shimadzu, Japan) (Anon, 2001).

\section{Statistical Analyses}

For the statistical design, a completely randomized experimental design was applied. The data in each analysis were subjected to a two-way ANOVA (SPSS 13.0 for Windows (SPSS Inc., 2004) with "temperature" and "the extent of heat treatment" as independent variables. The significant differences among the means are determined using Duncan's Multiple Range test. Differences were considered statistically significant when the probability was greater than $95 \%(P<0.05)$.

\section{RESULT and DISCUSSION}

\section{Changes in Chlorophyll Content}

Chlorophyll is responsible for the greenish coloration of certain olive oils. Those pigments are also important in olive oil stability. The thermal stability of chlorophyll in the VOO samples was determined for 0 , $2,4,6,8,10,12$, and 24 hours at 150, 160, 170, 180, 190 and $200^{\circ} \mathrm{C}$. The changes in the chlorophyll content at different temperature over time are shown in Figure 1. Two-way ANOVA results indicated that the interaction of temperature and the extent of heat treatment was significant $(P<0.05)$. 


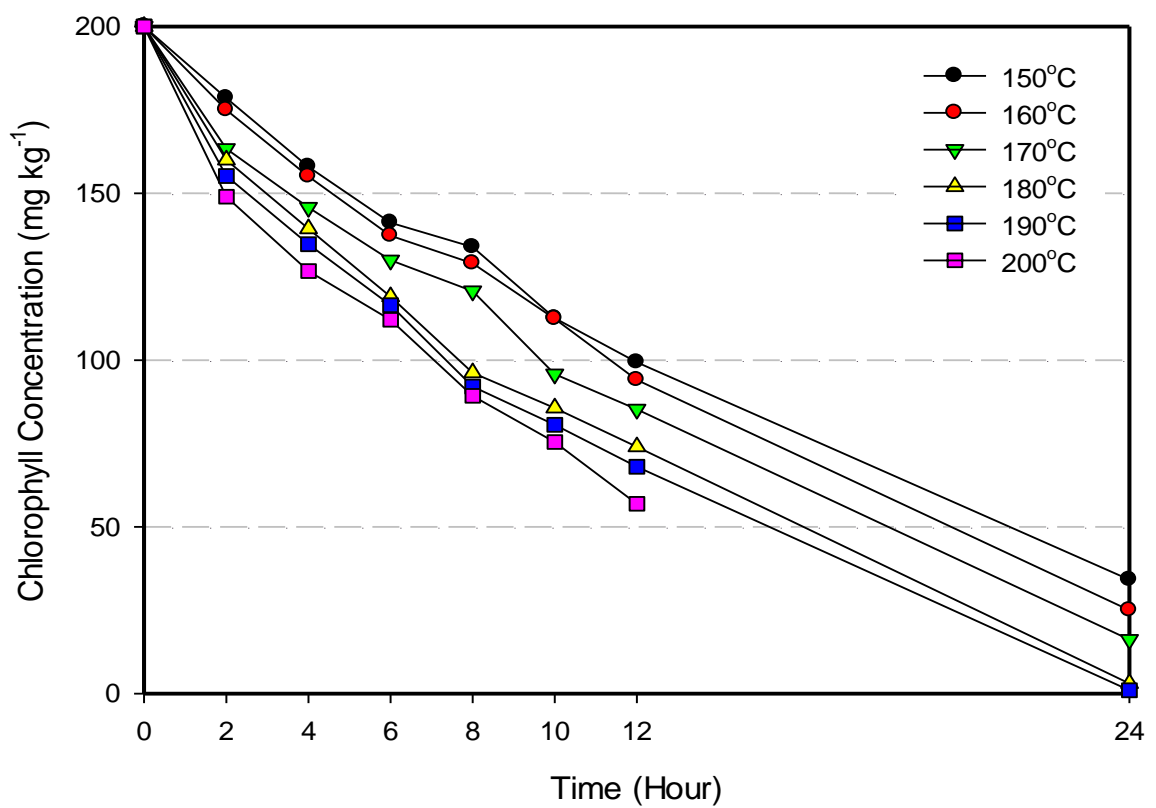

Figure 1. Effect of temperature on thermal stability of chlorophyll in VOO

The initial chlorophyll content of VOO was $200 \pm 0.57 \mathrm{mgkg}^{-1}$. It was found that the higher the treatment temperature, the lower the chlorophyll content in the VOO sample $(P<0.05)$. A $10^{\circ} \mathrm{C}$ increase in the temperature caused 2 to $15 \%$ decrease up to $12 \mathrm{~h}$, and 27 to $67 \%$ decrease up to $24 \mathrm{~h}$ in the chlorophyll content (Table 1). No chlorophyll was detected at $200^{\circ} \mathrm{C}$ after $24 \mathrm{~h}$ heat treatment.

Table 1. Changes in the chlorophyll content $\left(\mathrm{mgkg}^{-1}\right)$ of VOO

Extent of Heat Treatment (h)

\begin{tabular}{|c|c|c|c|c|c|c|c|c|}
\hline \multirow{2}{*}{ Temperature $\left({ }^{\circ} \mathrm{C}\right)$} & \\
\hline & 0 & 2 & 4 & 6 & 8 & 10 & 12 & 24 \\
\hline 150 & $200.0^{\mathrm{aH}}$ & $178.6^{\mathrm{dG}}$ & $158.0^{\mathrm{dF}}$ & $141.2^{\mathrm{dE}}$ & $133.9^{\mathrm{eD}}$ & $112.6^{\mathrm{e} C}$ & $99.4^{\text {f B }}$ & $34.1^{\mathrm{d} \mathrm{A}}$ \\
\hline 160 & $200.0^{\mathrm{a}, \mathrm{H}}$ & $175.0^{\mathrm{d} \mathrm{G}}$ & $155.1^{\mathrm{dF}}$ & $137.3^{\mathrm{dE}}$ & $129.0^{\mathrm{d} D}$ & $112.4^{\mathrm{e} C}$ & $94.1^{\text {e B }}$ & $25.0^{\mathrm{c} \mathrm{A}}$ \\
\hline 170 & $200.0^{\mathrm{aH}}$ & $163.4^{\mathrm{bc} G}$ & $145.8^{\mathrm{bc} F}$ & $130.0^{\mathrm{c} \mathrm{E}}$ & $120.7^{\mathrm{cD}}$ & $95.8^{\mathrm{dC}}$ & $85.2^{\mathrm{dB}}$ & $16.2^{\mathrm{bA}}$ \\
\hline 180 & $200.0^{\mathrm{aH}}$ & $160.0^{\mathrm{b} \mathrm{G}}$ & $139.4^{\mathrm{bF}}$ & $119.0^{\mathrm{bE}}$ & $96.2^{\mathrm{bD}}$ & $85.6^{\mathrm{cC}}$ & $74.0^{\mathrm{c} \mathrm{B}}$ & $3.0^{\mathrm{a} \mathrm{A}}$ \\
\hline 190 & $200.0^{\mathrm{aH}}$ & $155.2^{\mathrm{bG}}$ & $134.8^{\mathrm{bF}}$ & $116.5^{\mathrm{ab} E}$ & $92.1^{\mathrm{ab} D}$ & $80.6^{\mathrm{bC}}$ & $68.0^{\text {b B }}$ & $1.0^{\mathrm{a} \mathrm{A}}$ \\
\hline 200 & $200.0^{\mathrm{aG}}$ & $149.0^{\text {a } F}$ & $126.7^{\mathrm{aE}}$ & $112.1^{\mathrm{aD}}$ & $89.2^{\mathrm{a} C}$ & $75.4^{\text {a B }}$ & $56.9^{\text {a A }}$ & n.d. \\
\hline
\end{tabular}

Means followed by different letters within each column (series “a-f”) and each row (series "A-H”) are significantly different $(P<0.05)$, n.d.: not detected

The extent of heat treatment accelerated decomposition of chlorophyll in the VOO sample significantly $(P<0.05)$. The chlorophyll content decreased up to 71.6 and $99.5 \%$ of the initial value at the end of 12- and 24-h treatments, respectively. Especially high treatment temperatures (180, 190 and $200^{\circ} \mathrm{C}$ ) were found to have more detrimental effect on the stability of chlorophyll in VOO.

The findings indicate that chlorophyll is heat-labile and severely affected by the extent of heat treatment. These results are in good agreement with Ayadi and Grati-Kamun (2009), Malheiro et al. (2009) and Jaber et al. (2012) who reported more than $90 \%$ chlorophyll loss in olive oil samples.

\section{Changes in Conjugated Diene $\left(K_{232}\right)$ and Triene $\left(K_{270}\right)$ Contents}

The ultraviolet spectrophotometric analysis at 232 and $270 \mathrm{~nm}$ is simple and useful parameters for assessing the state of olive oil oxidation, being its values expressed as specific extinction coefficients. $\mathrm{K}_{232}$ is a measure of the primary oxidation products, conjugated dienes, which are formed by a shift in one of the double bonds. $\mathrm{K}_{270}$ is the indicative of conjugated trienes (the primary oxidation products) and secondary oxidation products such as aldehydes and ketons (Kiritsakis et al., 2002). The maximum values permitted for $K_{232}$ and $K_{270}$ are respectively 2.50 and 0.20 for extra VOO, and 2.60 and 0.25 for VOO, respectively (Annexes II and IX in European Community Regulation EEC/2568/91). 
The conjugated diene content $\left(\mathrm{K}_{232}\right.$ value $)$ of the VOO sample was determined for $0,2,4,6,8,10,12$, and 24 hours at 150,160,170,180,190 and $200^{\circ} \mathrm{C}$. Figure 2 shows the changes in $\mathrm{K}_{232}$ specific extinction coefficient at different temperature over time. It was found that the interaction of temperature and the extent of heat treatment significantly affected the $\mathrm{K}_{232}$ specific extinction coefficient $(P<0.05)$.

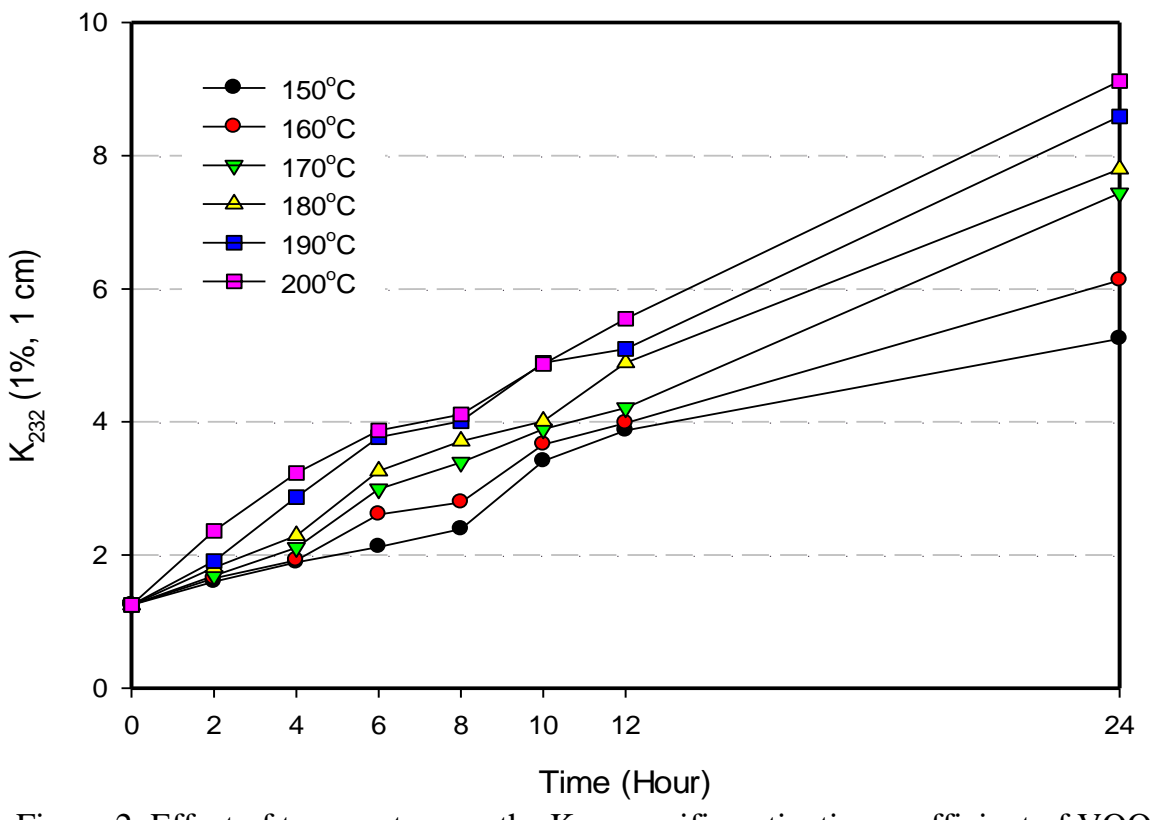

Figure 2. Effect of temperature on the $\mathrm{K}_{232}$ specific extinction coefficient of VOO

The initial $\mathrm{K}_{232}$ specific extinction coefficient of VOO was $1.25 \pm 0.13(1 \%, 1 \mathrm{~cm})$. The increase in the temperature increased the $\mathrm{K}_{232}$ specific extinction coefficient significantly $(P<0.05)$, and reached up to $9.12(1 \%, 1 \mathrm{~cm})$ at $200^{\circ} \mathrm{C}$ after $24 \mathrm{~h}$ of heat treatment
(Table 2). Every $10^{\circ} \mathrm{C}$ increase from 150 to $200^{\circ} \mathrm{C}$ resulted in 4 to 7 times increase in the $K_{232}$ specific extinction coefficient, indicating that higher temperatures had more effective on the formation of conjugated dienes in VOO.

Table 2. Changes in the $\mathrm{K}_{232}$ specific extinction coefficient of VOO

\begin{tabular}{|c|c|c|c|c|c|c|c|c|}
\hline \multirow[b]{2}{*}{ Temperature $\left({ }^{\circ} \mathrm{C}\right)$} & \multicolumn{8}{|c|}{ Extent of heat treatment (h) } \\
\hline & 0 & 2 & 4 & 6 & 8 & 10 & 12 & 24 \\
\hline 150 & $1.25^{\mathrm{a} \mathrm{A}}$ & $1.60^{\mathrm{a} \mathrm{B}}$ & $1.89^{\mathrm{a} C}$ & $2.12^{\mathrm{aD}}$ & $2.39^{\mathrm{a} E}$ & $3.41^{\mathrm{aF}}$ & $3.87^{\mathrm{aG}}$ & $5.25^{\mathrm{aH}}$ \\
\hline 160 & $1.25^{\mathrm{a} \mathrm{A}}$ & $1.65^{\mathrm{ab} B}$ & $1.92^{\mathrm{aC}}$ & $2.61^{\mathrm{bD}}$ & $2.79^{\mathrm{bE}}$ & $3.66^{\mathrm{bF}}$ & $3.98^{\mathrm{bG}}$ & $6.13^{\mathrm{bH}}$ \\
\hline 170 & $1.25^{\mathrm{aA}}$ & $1.69^{\mathrm{b} \mathrm{B}}$ & $2.11^{\mathrm{bC}}$ & $2.99^{\mathrm{cD}}$ & $3.39^{\mathrm{cE}}$ & $3.89^{\mathrm{cF}}$ & $4.21^{\mathrm{cG}}$ & $7.44^{\mathrm{c} \mathrm{H}}$ \\
\hline 180 & $1.25^{\mathrm{a} \mathrm{A}}$ & $1.81^{\mathrm{c} \mathrm{A}}$ & $2.29^{\mathrm{c} C}$ & $3.26^{\mathrm{dD}}$ & $3.71^{\mathrm{dE}}$ & $4.01^{\mathrm{dF}}$ & $4.89^{\mathrm{dG}}$ & $7.80^{\mathrm{dH}}$ \\
\hline 190 & $1.25^{\mathrm{a} \mathrm{A}}$ & $1.91^{\mathrm{d} \mathrm{B}}$ & $2.87^{\mathrm{dC}}$ & $3.77^{\text {e D }}$ & $4.01^{\mathrm{e} E}$ & $4.89^{\mathrm{e} F}$ & $5.10^{\mathrm{eG}}$ & $8.59^{\mathrm{e} H}$ \\
\hline 200 & $1.25^{\mathrm{aA}}$ & $2.36^{\mathrm{eB}}$ & $3.23^{\mathrm{eC}}$ & $3.87^{\mathrm{fD}}$ & $4.11^{\mathrm{fE}}$ & $4.87^{\mathrm{eF}}$ & $5.55^{\mathrm{fG}}$ & $9.12^{\mathrm{fH}}$ \\
\hline
\end{tabular}

Means followed by different letters within each column (series "a-f") and each row (series "A-H") are significantly different $(P<0.05)$.

It was found that the higher the extent of heat treatment, the higher the $\mathrm{K}_{232}$ specific extinction coefficient in the VOO sample $(P<0.05)$. When the extent of heat treatment increased from 0 to $24 \mathrm{~h}$ the $\mathrm{K}_{232}$ specific extinction coefficient increased around $1.6 \pm 0.2$ times. However, the rate of the increase in $K_{232}$ specific extinction coefficient did not change with the 2$\mathrm{h}$ increment in the heat treatment $(P<0.05)$, indicating that the formation of conjugated dienes in VOO occurred almost same rate.
The conjugated triene content $\left(\mathrm{K}_{270}\right)$ of the VOO sample was determined for $0,2,4,6,8,10,12$, and 24 hours at 150,160,170,180, 190 and $200^{\circ} \mathrm{C}$. The changes in $\mathrm{K}_{270}$ specific extinction coefficient at different temperature over time are illustrated in Figure 3. The result of two-way analysis of variance (ANOVA) indicated that the interaction of temperature and the extent of heat treatment significantly affected the $\mathrm{K}_{270}$ specific extinction coefficient $(P<0.05)$. 


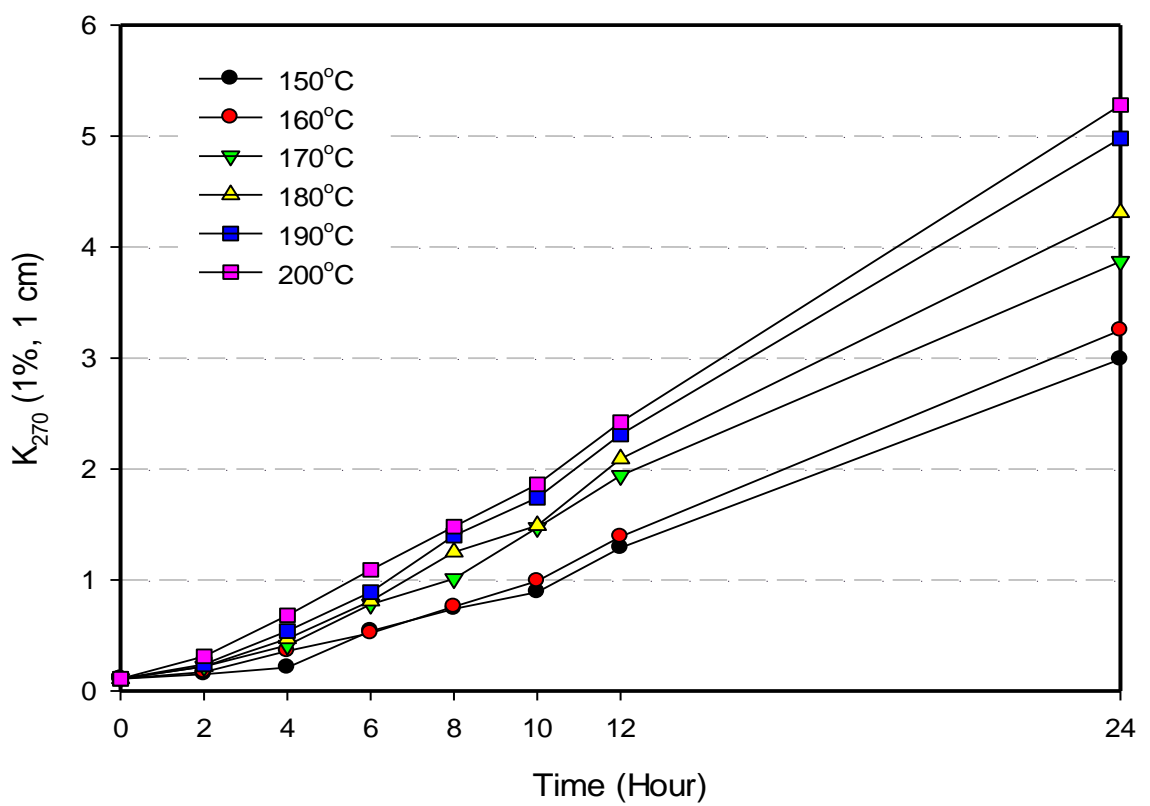

Figure 3. Effect of temperature on the $\mathrm{K}_{270}$ specific extinction coefficient of VOO

The initial $\mathrm{K}_{270}$ specific extinction coefficient of VOO was $0.11 \pm 0.03(1 \%, 1 \mathrm{~cm})$. It was found that the greater the temperature, the greater was the increase in the $\mathrm{K}_{270}$ specific extinction coefficient. The $\mathrm{K}_{270}$ specific extinction coefficient significantly increased when the temperature increased $(P<0.05)$, and reached up to 5.28 $(1 \%, 1 \mathrm{~cm})$ at $200^{\circ} \mathrm{C}$ after $24 \mathrm{~h}$ of heat treatment (Table $3)$. Every $10^{\circ} \mathrm{C}$ increase from 150 to $200^{\circ} \mathrm{C}$ accelerated the $\mathrm{K}_{270}$ specific extinction coefficient about 27 to 48 times, indicating that higher temperatures had more effective on the formation of conjugated trienes in VOO.

It was observed that when the extent of heat treatment was increased, the $\mathrm{K}_{270}$ specific extinction coefficient in the VOO sample was increased significantly $(P<0.05)$. When the extent of heat treatment increased from 0 to $24 \mathrm{~h}$ the $\mathrm{K}_{270}$ specific extinction coefficient increased around $2.2 \pm 0.5$ times. However, the rate of the increase in $\mathrm{K}_{270}$ specific extinction coefficient did not change with the 2-h increment in the heat treatment $(P<0.05)$, indicating that the formation of conjugated trienes in VOO occurred almost same rate.

These experimental results are in agreement with the expectation because the formation of conjugated $-\mathrm{C}=\mathrm{C}$ $\mathrm{C}=\mathrm{C}-\mathrm{C}=\mathrm{C}$ - double bond system is improbable even in the case of linolenic acid oxidation. The $-\mathrm{C}=\mathrm{C}-\mathrm{C}=\mathrm{C}-$ $\mathrm{C}=\mathrm{O}$ systems are more probable, and could interfere with the measurement at $270 \mathrm{~nm}$. The value of $\mathrm{K}_{232}$ and $\mathrm{K}_{270}$ specific extinction coefficients in this study exceeded the limits established by European Community Regulation (Annexes II and IX in $\mathrm{EEC} / 2568 / 91$ ) for VOO.

Table 3. Changes in the $\mathrm{K}_{270}$ specific extinction coefficient of VOO

\begin{tabular}{|c|c|c|c|c|c|c|c|c|}
\hline \multirow[b]{2}{*}{ Temperature $\left({ }^{\circ} \mathrm{C}\right)$} & \multicolumn{8}{|c|}{ Extent of heat treatment (h) } \\
\hline & 0 & 2 & 4 & 6 & 8 & 10 & 12 & 24 \\
\hline 150 & $0.11^{\mathrm{a} \mathrm{A}}$ & $0.15^{\text {a A }}$ & $0.21^{\mathrm{aA}}$ & $0.54^{\text {a B }}$ & $0.74^{\mathrm{aC}}$ & $0.89^{\text {a D }}$ & $1.29^{\mathrm{a} E}$ & $2.99^{\mathrm{aF}}$ \\
\hline 160 & $0.11^{\text {a A }}$ & $0.17^{\text {a A }}$ & $0.36^{\mathrm{b} \mathrm{B}}$ & $0.52^{\text {a. } C}$ & $0.76^{\mathrm{aD}}$ & $0.99^{\mathrm{a} E}$ & $1.39^{\mathrm{aF}}$ & $3.25^{\mathrm{bG}}$ \\
\hline 170 & $0.11^{\text {a A }}$ & $0.22^{\mathrm{b} \mathrm{A}}$ & $0.41^{\mathrm{b} \mathrm{B}}$ & $0.78^{\mathrm{bC}}$ & $1.01^{\mathrm{bD}}$ & $1.47^{\mathrm{bE}}$ & $1.94^{\mathrm{bF}}$ & $3.87^{\mathrm{c} \mathrm{G}}$ \\
\hline 180 & $0.11^{\text {a A }}$ & $0.22^{\mathrm{b} \mathrm{A}}$ & $0.47^{\mathrm{bc} \mathrm{B}}$ & $0.81^{\mathrm{bc} C}$ & $1.25^{\mathrm{cD}}$ & $1.49^{\mathrm{bE}}$ & $2.09^{\mathrm{cF}}$ & $4.31^{\mathrm{d} \mathrm{G}}$ \\
\hline 190 & $0.11^{\text {a A }}$ & $0.24^{\mathrm{bB}}$ & $0.54^{\mathrm{cC}}$ & $0.89^{\mathrm{cD}}$ & $1.40^{\mathrm{dE}}$ & $1.74^{\mathrm{c} \mathrm{F}}$ & $2.31^{\mathrm{d} G}$ & $4.98^{\mathrm{eH}}$ \\
\hline 200 & $0.11^{\mathrm{aA}}$ & $0.31^{\mathrm{cB}}$ & $0.68^{\mathrm{dC}}$ & $1.09^{\mathrm{d} D}$ & $1.48^{\mathrm{dE}}$ & $1.86^{\mathrm{dF}}$ & $2.42^{\mathrm{d} \mathrm{G}}$ & $5.28^{\mathrm{fH}}$ \\
\hline
\end{tabular}

Means followed by different letters within each column (series "a-f") and each row (series "A-H") are significantly different $(P<0.05)$.

These results are in good agreement with the previous studies in which different storage or treatment temperature and time accelerated the value of $\mathrm{K}_{232}$ and $\mathrm{K}_{270}$ specific extinction coefficients in VOO (Caponio et 
al., 2005; Allouche et al., 2007; Bester et al., 2008; Ayadi and Grati-Kamun, 2009; Mahmoud et al., 2009; Malheiro et al., 2009; Farhoosh et al., 2012).

\section{Correlation of Chlorophyll Content with Specific} Extinction Coefficients

The relationship between the changes in the chlorophyll and conjugated diene $\left(\mathrm{K}_{232}\right)$ and triene $\left(\mathrm{K}_{270}\right)$ contents with temperature and the extent of heat treatment was studied by regression analysis. The relationship was found to be significant $(P<0.05)$, and chlorophyll content inversely related to $\mathrm{K}_{232}$ and $\mathrm{K}_{270}$ specific extinction coefficients.

The coefficient of determination $\left(\mathrm{R}^{2}\right)$ was higher than 0.95 for $\mathrm{K}_{232}$ specific extinction coefficient and 0.88 for $\mathrm{K}_{270}$ specific extinction coefficient, indicating a good correlation between the chlorophyll content and the $\mathrm{K}_{232}$ and $K_{270}$ specific extinction coefficients (Table 4). Our findings are in agreement with those of Malheiro et al. (2009).

Table 4. Linear regression analysis between chlorophyll content and $\mathrm{K}_{232}$ and $\mathrm{K}_{270}$ specific extinction coefficients

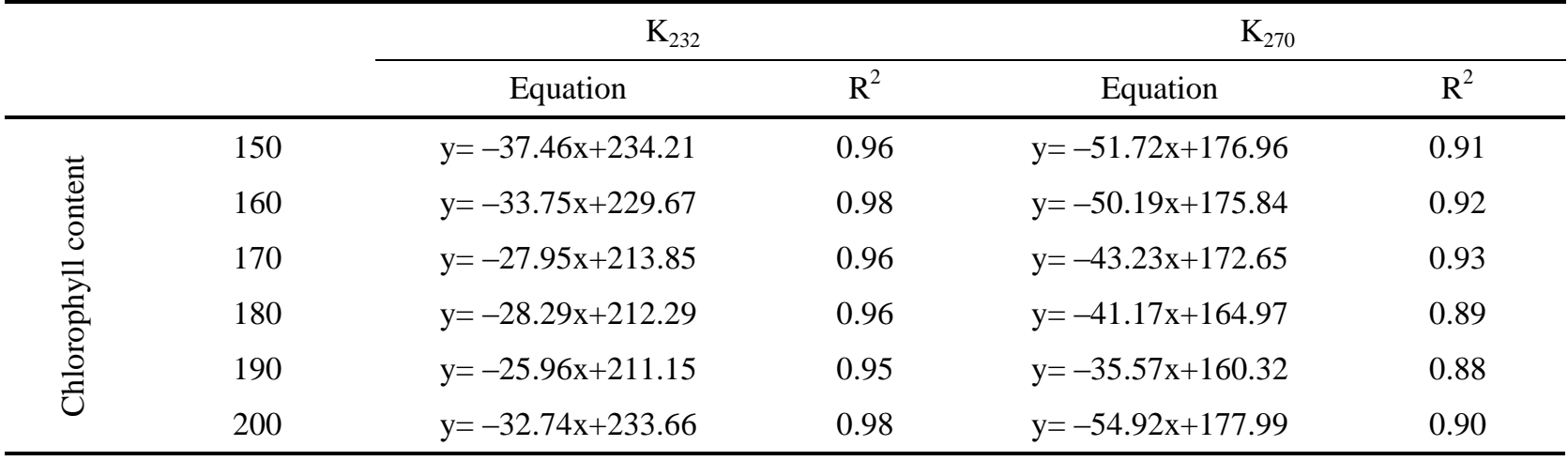

\section{CONCLUSION}

This study evaluated the changes in chlorophyll content and oxidative stability of virgin olive oil at the temperatures between 150 and $200^{\circ} \mathrm{C}$ during 24 hours.

During heat treatment, a decrease in the chlorophyll content and an increase in the UV absorbance values $\left(\mathrm{K}_{232}\right.$ and $\left.\mathrm{K}_{270}\right)$ took place in $\mathrm{VOO}$, as the measure of oxidative degradation of VOO. Significant differences were found among the oil samples treated at different temperature and time at $5 \%$ significance level.

The thermo-oxidative stability of VOO was higher at high temperature and for long treatment time. Chlorophyll content decreased around $99.5 \%$ at $200^{\circ} \mathrm{C}$ after $24 \mathrm{~h}$ of heat treatment. $\mathrm{K}_{232}$ and $\mathrm{K}_{270}$ specific extinction coefficients of VOO exceeded the maximum allowable limits of the European Community Regulation at the experimental conditions used, being not considered as VOO anymore. These results showed that VOO is not suitable for high temperature processes.

Linear regression analysis was able to predict VOO degradation in terms of chlorophyll content and $\mathrm{K}_{232}$ and $\mathrm{K}_{270}$ specific extinction coefficients. The coefficient of determination $\left(\mathrm{R}^{2}\right)$ ranged between 0.88 and 0.98 , indicating that determination of chlorophyll content and $\mathrm{K}_{232}$ and $\mathrm{K}_{270}$ specific extinction coefficients was assigned as the useful markers of oxidative status of VOO.

\section{REFERENCES}

Allouche, Y., Jimenez, A., Gaforio, J.J., Uceda, M., Beltran, G. 2007. How Heating Affects Extra Virgin Olive Oil Quality Indexes and Chemical Composition. Journal of Agricultural and Food Chemistry, 55:9646-9654.
Angerosa, F. 2002. Influence of Volatile Compounds on Virgin Olive Oil Quality Evaluated by Analytical Approaches and Sensor Panels. European Journal of Lipid Science and Technology, 104:639-660.

Angerosa, F., Campestre, C., Giansante, L. 2006. Analysis and Authentication. In: Olive Oil: Chemistry and Technology (Editor: Boskou, D.). AOCS Press, IL. pp. 113-172.

Anonymous, 2001. Spectrophotometric Investigation in the Ultraviolet. COI/T20/Doc. no. 19/Rev.1. International Olive Oil Council, Spain.

Anonymous, 2004. International Conference on the Health Effect of Virgin Olive Oil. European Journal of Clinical Investigation, 35:421-424.

Aparicio, R., Roda, L., Albi, M.A., Gutiérrez, F. 1999. Effect of Various Compounds on Virgin Olive Oil Stability Measured by Rancimat. Journal of Agricultural and Food Chemistry, 47:4150-4155.

Ayadi, M.A., Grati-Kamun, N.H. 2009. PhysicoChemical Change and Heat Stability of Extra Virgin Olive Oils Flavored by Selected Tunisian Aromatic Plants. Food Chemistry and Toxicology, (47): 26132619.

Bester, E., Butinar, B., Bucar-Miklavcic, M., Golob, T. 2008. Chemical Changes in Extra Virgin Olive Oils from Slovenian Istra after Thermal Treatment. Food Chemistry, 108:446-454.

Boskou, D. 2006. Characteristics of the Olive Tree and Olive Fruit. In: Olive Oil: Chemistry and Technology (Editor: Boskou, D.). AOCS Press, IL. pp. 13-19. 
Boskou, D., Blekas, G., Tsimidou, M. 2006. Olive Oil Composition. In: Olive Oil: Chemistry and Technology (Editor: Boskou, D.). AOCS Press, IL. pp. 41-72.

Caponio, F., Bilancia, M.T., Pasqualone, A., Sikorska, E., Gomes, T. 2005. Influence of the Exposure to Light on Extra Virgin Olive Oil Quality during Storage. European Food Research and Technology, 221:92-98.

Chen, B.H., Liu, M.H. 1998. Relationship between Chlorophyll a and $\beta$-Carotene in a Lipid-Containing Model System during Illumination. Food Chemistry, 63:207-213.

Cichelli, A., Pertesana, G.P. 2004. High-Performance Liquid Chromatographic Analysis of Chlorophylls, Pheophytins and Carotenoids in Virgin Olive Oils: Chemometric Approach to Variety Classification. Journal of Chromatography A, 1046:141-146.

Del Giovine, L., Fabietti, F. 2005. Copper Chlorophyll in Olive Oils: Identification and Determination by LIF Capillary Electrophoresis. Journal of Food Control, 16:267-272.

Endo, Y., Usuki, R., Kaneda, T. 1984. Prooxident Activities of Chlorophylls and Their Decomposition Products on the Photooxidation of Methyl Linoleate. Journal of the American Oil Chemists' Society, 61:781-784.

Farhoosh, R., Khodaparast, M.H.H., Sharif, A., Rafiee, S.A. 2012. Olive Oil Oxidation: Rejection Points in terms of Polar, Conjugated Diene, and Carbonyl Value. Food Chemistry, 131: 1385-1390.

Jaber, H., Ayadi, M., Makni, J., Rigane, G., Sayadi, S., Bouaziz, M. 2012. Stabilization of Refined Olive Oil by Enrichment with Chlorophyll Pigments Extracted from Chemlali Olive Leaves. European Journal of Lipid Science and Technology, 114:1274-1283.

Kiritsakis, A., Kanavouras, A., Kritsakis, K., 2002. Chemical Analysis, Quality Control and Packaging Issues of Olive Oil. European Journal of Lipid Science and Technology, 104:628-638.
Mahmoud, E.A.E-.M., Dostalova, J., Pokorny,J., Lukesova, D., Dolezal M. 2009. Oxidation of Olive Oils during Microwave and Conventional Heating for Fast Food Preparation. Czech Journal of Food Sciences, 27:S173-S177.

Malheiro, R., Oliveira, I., Vilas-Boas, M., Falcão, S., Bento, A., Pereira, J.A. 2009. Effect of Microwave Heating with Different Exposure Times on Physical and Chemical Parameters of Olive Oil. Food and Chemical Toxicology, 47:92-97.

Morello, J.-R., Motilva, M.-J., Tovar, M.-J., Romero, M.-P. 2004. Changes in Commercial Virgin Olive Oil (cv Arbequina) during Storage, with Special Emphasis on the Phenolic Fraction. Food Chemistry, 85:357-364.

Ozyilkan, O., Colak, D., Akcali, Z., Basturk, B. 2005. Olive: Fruit of Peace against Cancer. Asian Pacific Journal of Cancer Prevention, 6:77-82.

Perez-Jimenez, F., Ruano, J., Perez-Martinez, P., Lopez-Segura, F., Lopez-Miranda, J. 2007. The Influence of Olive Oil on Human Health: Not a Question of Fat Alone. Molecular Nutrition Food Research, 51:1199-1208.

Pokorny, J., Kalinova, L., Dysseler, P. 1995. Determination of Chlorophyll Pigments in Crude Vegetable Oils. Pure \& Applied Chemistry, 67:1781-1787.

Rahmani, M., Csallany, A.S. 1998. Role of Minor Constituents in the Photooxidation of Virgin Olive Oil. Journal of the American Oil Chemists' Society, 75:837-843.

Tsimidou, M.Z. 2006. Olive Oil Quality. In: Olive Oil: Chemistry and Technology (Editor: Boskou, D.). AOCS Press, IL. pp. 93-111.

Visioli, F., Bogani, P., Galli, P., 2006. Healthful Properties of Olive Oil Minor Components. In: Olive Oil: Chemistry and Technology (Editor: Boskou, D.). AOCS Press, IL. pp. 173-190. 